\title{
Hubungan Cedera Servikal dengan Fraktur Depresi Tulang Frontal pada Cedera Kepala Ringan
}

\author{
Muhammad Zafrullah Arifin, Wienorman Gunawan \\ Departemen Bedah Saraf Fakultas Kedokteran Universitas Padjajaran- \\ Rumah Sakit Dr. Hasan Sadikin, Bandung
}

\begin{abstract}
Abstrak
Pemahaman mekanisme cedera kepala penting dalam menentukan pola cedera secara anatomis. Fraktur depresi tulang frontal terjadi bila terdapat gaya mekanis yang cukup kuat pada kepala. Dalam hal ini pada aksis fleksi dan ekstensi. Gerakan fleksi ekstensi berlebihan dilaporkan berhubungan dengan cedera servikal. Penelitian analitik retrospektif di Departemen Bedah Saraf RS Dr. Hasan Sadikin Bandung periode Januari 2008-Desember 2009 ini bertujuan untuk melihat hubungan cedera servikal dengan fraktur depresi tulang frontal pada penderita cedera kepala ringan. Uji statistik menggunakan chi-kuadrat dan Pearson correlation. Didapatkan 354 kasus cedera kepala ringan dengan 17 (4,8\%) kasus fraktur depresi tulang frontal, 14 (3,9\%) kasus cedera servikal termasuk satu kasus dengan keduanya. Mekanisme cedera kepala terbanyak adalah kecelakaan bermotor, terjatuh dari ketinggian, dan benturan benda tumpul di bagian kepala. Hasil analisis statistik menunjukkan hubungan signifikan fraktur depresi tulang frontal dengan cedera servikal $(\mathrm{p}=0,000)$. Tidak didapatkan hubungan penggunaan helm dengan risiko cedera servikal $(p=0,157)$. Simpulan, fraktur depresi tulang frontal pada kasus cedera kepala ringan merupakan indikator adanya cedera servikal. [MKB. 2011;43(3):122-7].
\end{abstract}

Kata kunci: Cedera kepala ringan, cedera servikal, fraktur depresi tulang frontal

\section{Correlation of Cervical Injury to Frontal Depressed Fracture in Mild Head Injury}

\begin{abstract}
An understanding of head injury mechanism has a major role in predicting the anatomical injury. Frontal depressed fracture occurs if a substantial force is applied to the head. In this case, the flexion and extension axis. Overflexion and over-extension movement was reported to have correlation with cervical injury. This study was to find out the correlation cervical injury and frontal depresses fracture in mild head injury cases. A retrospective analytic study was carried out, chi-square and Pearson correlation test were performed using records of patients consulted to Neurosurgery Department of Dr. Hasan Sadikin Hospital in January 2008-December 2009. There were 354 cases of mild head injury with $17(4.8 \%)$ cases of frontal depressed fracture, $14(3.9 \%)$ cervical injuries, included one with both. The cause of the trauma were riding motorcycle, fell from height, and blunt trauma to the head. The statistical analysis showed a significant correlation between cervical injury and frontal depressed fracture $(p=0.000)$. There was no correlation between helmet utilization and risk of cervical injury $(p=0.157)$. In conclusion, fracture in mild head injury cases is an indicator of cervical injury. [MKB. 2011;43(3):122-7].
\end{abstract}

Key words: Cervical injury, mild head injury, frontal depressed fracture

\footnotetext{
Korespondensi: Muhammad Zafrullah Arifin, dr., Sp.BS, Departemen Bedah Saraf Fakultas Kedokteran Universitas Padjadjaran-Rumah Sakit Dr. Hasan Sadikin, jalan Pasteur 38 Bandung, telepon (022) 2038436, mobile 0811221325, e-mail:wienormangunawan@yahoo.co.id
} 


\section{Pendahuluan}

Pencegahan cedera neurologis selalu lebih baik daripada menunggu timbulnya gejala patologis atau komplikasi dari cedera tulang atau cedera neurologis maupun gejala sekunder akibat ketidakstabilan kardiovaskular atau insufisiensi pernapasan yang diakibatkan cedera neurologis tersebut. Seperti halnya pada semua penderita trauma, evaluasi klinis awal dan manajemennya dimulai dengan survei primer. Survei primer berfokus pada deteksi kondisi yang mengancam jiwa dan stabilisasi keadaan yang mengancam tersebut.

Pemahaman tentang mekanisme kejadian cedera dan tenaga mekanis yang menyertai kejadian cedera penting dalam menentukan pola cedera yang terjadi secara anatomis. ${ }^{1}$ Fraktur depresi pada tulang frontal terjadi bila ada gaya mekanis yang cukup kuat pada aksis kepala. Kekuatan gaya fleksi-ekstensi kepala selama gaya mekanis berlangsung dapat ikut mencederai servikal. ${ }^{2,3}$ Gerakan fleksi-ekstensi berlebihan seperti pada fraktur depresi tulang frontal berhubungan erat dengan adanya kelainan pada servikal penderita yang hanya $2 \%$ dan terbukti disertai kelainan pada servikal, ${ }^{4,5}$ serta risiko cedera servikal meningkat dengan beratnya kasus cedera kepala. Banyak peneliti meyakini bahwa data mengenai mekanisme cedera sangat membantu memprediksi kemungkinan kerusakan dan beratnya cedera yang terjadi, sedangkan sebagian lagi lebih yakin dengan penilaian keadaan klinis penderita saat datang, misalnya dengan melihat temuan jejas di dada, perut, leher, dan keluhan penderita. ${ }^{1}$ Hingga kini panduan dari Advance Trauma Life Support (ATLS) dalam manajemen trauma adalah imobilisasi semua penderita dengan jejas di atas klavikula.

Tulang kepala manusia memiliki ketebalan yang berbeda-beda. Bagian yang dilapisi otot memiliki jenis tulang yang lebih tipis, karena adanya peredam berupa otot tersebut, dan sebaliknya, tulang yang tidak dilapisi otot lebih memiliki ketebalan. Tulang frontal tidak memiliki otot dan mempunyai ketebalan lebih dibandingkan dengan tulang temporal dan oksipital. Cedera pada tulang frontal dapat berupa fraktur linear dan fraktur depresi. Fraktur depresi tulang frontal merupakan akibat adanya benturan energi tinggi pada permukaan yang sempit pada tulang frontal. ${ }^{6}$ Dikatakan bahwa diperlukan kekuatan sebesar 10 hingga 15 kali gaya gravitasi untuk menciptakan cedera berupa fraktur depresi pada tulang frontal. Suatu fraktur depresi dapat terbuka dan dapat tertutup, fraktur depresi yang terbuka sendiri dapat merupakan luka bersih dan dapat juga terkontaminasi. Dilaporkan bahwa
$25 \%$ penderita dengan cedera fraktur depresi mengalami penurunan kesadaran. Besarnya energi yang diperlukan untuk mengakibatkan fraktur frontal membutuhkan benturan keras, yaitu lebih dari 50 kali gaya gravitasi bumi. ${ }^{6}$ Insidensi cedera servikal yang berhubungan dengan fraktur frontal pernah dilaporkan hanya sebesar $0,2-0,6 \%{ }^{7}$

Cedera servikal sendiri dapat dikategorikan berdasarkan mekanisme cedera antara lain fleksi, fleksi rotasi, ekstensi, ekstensi rotasi, kompresi vertikal, lateral fleksi, dan mekanisme idiopatik yang mengakibatkan fraktur odontoid dan dislokasi atlanto-oksipital. ${ }^{2,3,8}$ Hampir sepertiga kasus cedera servikal terjadi pada level vertebra servikal kedua, namun tidak dijelaskan penyebab terbanyak pada level tersebut. ${ }^{4,5}$ Penggunaan helm sendiri dikatakan tidak berpengaruh banyak pada cedera kepala, bahkan pada beberapa penelitian menunjukkan bahwa tingkat mortalitas penderita dengan cedera kepala tidak dipengaruhi oleh penggunaan helm. ${ }^{9,10}$ Namun, pada penelitian lain dikatakan juga bahwa penggunaan helm sendiri dapat meningkatkan risiko terjadinya cedera servikal akibat bertambahnya berat kepala yang kemudian menambah gaya fleksi ekstensi saat terjadinya mekanisme cedera. Tidak dijelaskan mengenai tipe dan beratnya helm yang dianggap dapat meningkatkan risiko tersebut. Hal ini juga yang mendasari diproduksinya pakaian head and neck support (HANS) yang biasa digunakan oleh pembalap. ${ }^{9}$

Penelitian ini bertujuan untuk membuktikan adanya hubungan antara risiko cedera servikal dan fraktur depresi tulang frontal pada penderita cedera kepala ringan.

\section{Metode}

Penelitian ini merupakan penelitian analitik retrospektif. Data diambil dari catatan medis penderita yang berobat ke Unit Gawat Darurat Rumah Sakit Dr. Hasan Sadikin dengan riwayat trauma kepala. Kriteria inklusi adalah semua kasus yang didiagnosis cedera kepala ringan dengan skor Glasgow coma scale 14 atau 15 saat diterima oleh Departemen Bedah Saraf Rumah Sakit Dr. Hasan Sadikin, penderita cedera kepala ringan disertai cedera pada daerah servikal baik dengan maupun tanpa gejala neurologis dengan maupun tanpa bukti abnormalitas radiologis, penderita cedera kepala ringan yang disertai fraktur depresi tulang frontal tertutup maupun terbuka, lebih maupun kurang dari satu tabula. Data penderita yang dikumpulkan adalah usia, jenis kelamin, diagnosis kerja, mekanisme terjadinya cedera, lokasi jejas, dan penggunaan helm saat kejadian trauma (khusus pada mekanisme cedera berupa 
pengendara dan penumpang kendaraan roda dua). Uji statistik menggunakan Pearson correlation test dengan tingkat kepercayaan 95\%.

\section{Hasil}

Didapatkan 354 subjek cedera kepala ringan (Tabel 1) dengan 14 kasus cedera servikal, 17 kasus fraktur depresi tulang frontal, dan 1 kasus fraktur depresi tulang frontal yang disertai cedera servikal (Tabel 2). Terdapat 105 (29,7\%) penderita wanita dan 249 (70,3\%) laki-laki (Tabel 1). Penyebab trauma adalah kecelakaan kendaraan bermotor, jatuh dari ketinggian, dan cedera akibat benturan benda tumpul. Cedera kepala ringan yang diakibatkan jatuh dari kendaraan bermotor hanya 95 penderita dari 216 kasus yang menggunakan helm. Hanya 4 dari 17 kasus cedera fraktur depresi tulang frontal yang menggunakan helm saat kejadian trauma (Tabel 3).

Untuk melihat hubungan antara fraktur depresi tulang frontal dan cedera servikal dapat dilihat pada Tabel 2. Uji statistik dengan chikuadrat menunjukkan bahwa cedera servikal dan fraktur depresi tulang frontal saling berhubungan satu sama lainnya $(\mathrm{p}=0,000)$. Uji dengan Pearson correlation test pun menunjukkan hasil yang sama $\left(\mathrm{x}^{2}=0,935\right)$.

Mekanisme penyebab terjadinya cedera kepala paling banyak akibat kecelakaan kendaraan bermotor dengan penderita terbanyak adalah pengendara kendaraan roda dua $(47,2 \%)$ diikuti oleh penumpang kendaraan roda dua $(13,8 \%)$ (Tabel 1). Mekanisme cedera selebihnya diakibatkan oleh benturan benda tumpul pada kepala dan terjatuh dari ketinggian, sedangkan pada kelompok penderita dengan fraktur depresi tulang frontal, semua trauma memiliki mekanisme yang sama, yaitu kecelakaan kendaraan roda dua sebanyak $15 / 17$ penderita adalah pengendara kendaraan roda dua dan $2 / 17$ penderita adalah penumpang kendaraan roda dua. Hanya 4/17 penderita pada kelompok ini yang menggunakan helm saat terjadinya kecelakaan (Tabel 3).

Sayangnya data yang terperinci mengenai jenis helm yang digunakan, apakah helm setengah wajah half face atau helm yang menutup wajah full face, tidak terdokumentasi. Data ini tentu dapat membantu kita menentukan helm mana yang lebih efektif untuk mencegah terjadinya fraktur depresi tulang kepala maupun cedera servikal.

Risiko terjadinya cedera servikal lebih tinggi pada kelompok penderita yang menggunakan helm dibandingkan dengan penderita yang tidak menggunakan helm dan bila data sampel yang ada dimasukkan ke dalam perhitungan statistik Pearson correlation maka didapatkan hasil yang tidak bermakna $(p=0,157)$.

\section{Pembahasan}

Hasil penelitian ini mendapatkan 249 penderita laki-laki dan 105 penderita perempuan. Hasil ini sama dengan penelitian terdahulu dan

Tabel 1 Karakteristik Sampel dan Mekanisme Trauma

\begin{tabular}{|c|c|c|}
\hline Karakteristik & $\mathbf{n}$ & $(\%)$ \\
\hline \multicolumn{3}{|l|}{ Jenis kelamin } \\
\hline Laki-laki & 249 & $(70,3 \%)$ \\
\hline Wanita & 105 & $(29,7 \%)$ \\
\hline \multicolumn{3}{|l|}{ Mekanisme trauma } \\
\hline Jatuh dari ketinggian & 28 & $(7,9 \%)$ \\
\hline Jatuh terpeleset & 27 & $(7,6 \%)$ \\
\hline Penumpang kendaraan roda 2 & 49 & $(13,8 \%)$ \\
\hline Penumpang kendaraan roda 4 & 15 & $(4,2 \%)$ \\
\hline Tertabrak oleh motor & 16 & $(4,5 \%)$ \\
\hline Tertabrak oleh mobil & 11 & $(3,1 \%)$ \\
\hline Benturan benda tumpul pada kepala & 41 & $(11,6 \%)$ \\
\hline Pengendara kendaraan roda 2 & 167 & $(47.2 \%)$ \\
\hline \multicolumn{3}{|l|}{ Helm pada fraktur depresi tulang frontal } \\
\hline Menggunakan helm & 95 & $(44 \%)$ \\
\hline Tidak menggunakan helm & 121 & $(56 \%)$ \\
\hline \multicolumn{3}{|l|}{ Usia } \\
\hline Mean & \multicolumn{2}{|c|}{27,93 tahun } \\
\hline Median & \multicolumn{2}{|c|}{23 tahun } \\
\hline
\end{tabular}


Tabel 2 Tabulasi Silang Fraktur Depresi Tulang Frontal dan Cedera Servikal

\begin{tabular}{ccccc}
\hline \multirow{2}{*}{ Cedera servikal } & \multicolumn{2}{c}{ Fraktur Depresi Tulang Frontal } & \multirow{2}{*}{ Jumlah } & \multirow{2}{*}{ Kemaknaan } \\
\cline { 2 - 3 } & Ada & Tidak ada & & 14 \\
Ada & 1 & 13 & 16 & $\mathrm{X}^{2}=0,935$ \\
Tidak ada & 16 & 0 & 30 & $\mathrm{p}=0,000$ \\
Jumlah & 17 & 13 & \\
\hline
\end{tabular}

Keterangan: $\mathrm{X}^{2}=$ uji chi-kuadrat, nilai $\mathrm{p}$ atas dasar $\mathrm{p}<0,05$ bermakna

kepustakaan yang menyatakan bahwa kejadian trauma lebih sering terjadi pada laki-laki dengan perbandingan 2:1. ${ }^{1}$ Banyaknya penderita laki-laki dikarenakan sebagian besar penderita pengendara kendaraan roda dua (167 orang) adalah laki-laki. Pada kejadian fraktur depresi tulang frontal maupun cedera servikal, ternyata penderita lakilaki lebih banyak daripada perempuan, yaitu pada penderita laki-laki sebanyak 11 penderita cedera servikal dan 15 fraktur depresi tulang frontal, sedangkan penderita perempuan sebanyak 3 orang penderita cedera servikal dan 2 orang penderita fraktur depresi tulang frontal.

Kasus cedera servikal sendiri menempati 4,8\% dari seluruh kasus cedera kepala ringan. Data ini tidak berbeda jauh dari kepustakaan yang menyatakan bahwa hanya $2 \%$ penderita dengan cedera kepala menderita cedera servikal. ${ }^{6}$ Persentase pada penelitian ini hanya melibatkan cedera kepala ringan saja, bukan dari seluruh kejadian cedera kepala (ringan, sedang, dan berat). Perbedaan ini dapat disebabkan oleh karena kepustakaan tersebut mengambil data dari negara maju, penggunaan kendaraan roda dua tidak sebanyak di Indonesia yang kemudian menimbulkan perbedaan karakteristik sampel ditambah adanya perbedaan perilaku pengendara kendaraan roda dua tersebut.

Kelompok kasus dengan cedera servikal, hanya enam penderita yang terlibat dalam kecelakaan kendaraan bermotor, $3 / 6$ penderita pada kelompok ini menggunakan helm dan 3/6 penderita lagi tidak (Tabel 3). Penggunaan helm memiliki risiko kejadian cedera servikal. Sebagian peneliti berpendapat bahwa bertambahnya beban akibat penggunaan helm pada kepala saat terjadinya gerakan fleksi-ekstensi maksimal akan menambah gaya fleksi ekstensi yang diterima oleh servikal. ${ }^{4,6,10,15}$ Penelitian lanjut dengan jumlah sampel yang lebih besar dan lebih detil mengenai tipe helm yang digunakan akan membantu kita untuk menentukan beban tambahan pada kepala dan sekaligus beban ideal helm yang sebaiknya digunakan untuk mencegah risiko cedera pada

Tabel 3 Karakteristik Masing-masing Kelompok Variabel

\begin{tabular}{llc}
\hline Fraktur depresi tulang frontal & n (17) \\
\hline \multirow{2}{*}{ Jenis kelamin } & Laki-laki & 15 \\
& Wanita & 2 \\
Mekanisme & Pengendara kendaraan roda 2 & 15 \\
& Penumpang kendaraan roda 2 & 2 \\
Helm & Dengan helm & 4 \\
Cedera servikal & Tanpa helm & 13 \\
Jenis kelamin & Laki-laki & $\mathbf{n}(\mathbf{1 4})$ \\
& Wanita & 11 \\
& Pengendara kendaraan roda 2 & 3 \\
Mekanisme & Jatuh dari ketinggian & 5 \\
& Trauma tumpul di kepala & 5 \\
Cedera servikal karena & Pendaraan bermotor & 3 \\
& Dengan helm & 1 \\
& Tanpa helm & $\mathbf{n}(\mathbf{6})$ \\
\end{tabular}


kepala maupun servikal. Pada penelitian lain tidak ditemukan hubungan yang signifikan antara penggunaan helm dan cedera servikal, bahkan penggunaan helm dilaporkan sekaligus dapat menurunkan risiko cedera kepala primer. ${ }^{12-14}$

Penelitian ini menemukan bahwa hanya $17 / 354(4,8 \%)$ penderita dari total subjek yang mengalami fraktur depresi tulang frontal, sesuai dengan kepustakaan yang menyatakan bahwa kejadian cedera servikal pada kejadian fraktur depresi tulang frontal sebesar $0,6 \%$ hingga 5\% ${ }^{3,16}$ Penelitian ini juga menunjukkan cedera terbanyak terjadi pada level vertebra servikal keempat dan kelima. Hasil ini berbeda dengan kepustakaan yang menyatakan bahwa kejadian cedera terbanyak terjadi pada vertebra servikal kedua. ${ }^{2,4}$ Penderita paling banyak menderita cedera pada vertebra servikal kedua berupa dislokasi dengan mekanisme kompresi, distraksi, sekaligus rotasi yang diakibatkan kecelakaan kendaraan bermotor.

Perhitungan statistik untuk menilai hubungan antara cedera servikal dan fraktur depresi tulang frontal menggunakan uji chi-kuadrat dengan $\mathrm{X}^{2}=0,935$ didapatkan $\mathrm{p}=0,000$ (Tabel 2) yang menunjukkan bahwa terdapat hubungan yang signifikan antara cedera servikal dan fraktur depresi tulang frontal. Dibutuhkan penelitian lebih lanjut dengan subjek yang lebih besar dan melibatkan lebih banyak pusat kesehatan primer, sehingga manfaatnya dapat diterapkan dalam manajemen penderita trauma. Simpulan, fraktur depresi tulang frontal pada kasus cedera kepala ringan merupakan indikator adanya cedera servikal.

\section{Daftar Pustaka}

1. Thompson WL, Stiell IG, Clement CM, Brison RJ. Association of injury mechanism with the risk servikal spine fractures. CJEM. 2009;11:14-22.

2. Mardjono M, Sidharta P. Neurologi klinis dasar. Edisi ke-4. Jakarta: PT. Dian Rakyat; 1981.

3. Greenberg MS. Handbook of neurosurgery. Edisi ke-6. New York: Thieme; 2006.

4. Timothy R. Vertebral fracture. Updated: Apr 13, 2009 (diunduh 31 Maret 2010). Tersedia dari: URL: http://emedicine.medscape.com/ article/248236-overview.

5. Donald S. Spinal cord injuries. Updated: Apr 8, 2009 (diunduh 4 April 2010). Tersedia dari: URL: http://emedicine.medscape.com/ article/793582-overview.

6. Thomas W. Fracture frontal. Updated: Mar 6, 2008 (diunduh 4 April 2010). Tersedia dari: URL: http://emedicine.medscape.com/ article/825169-overview.

7. Qureshi NH. Skull fracture. Updated: Nov 10, 2009 (diunduh 31 Maret 2010). Tersedia dari: URL: http://emedicine.medscape.com/ article/248108-media.

8. Moira D. Fracture cervical spine. Updated: Oct 30, 2009 (diunduh 31 Maret 2010). Tersedia dari: URL: http://emedicine.medscape.com/article/824380-diagnosis.

9. Luna GK, Copass MK, Oreskovich MR, Carrico CJ. The role of helmets in reducing head injuries from motorcycle accidents: a political or medical issue. West J Med. 1981;135:89-92.

10. Sanfelipo TP. Understanding head \& neck trauma (diunduh 4 April 2010). Tersedia dari: URL: http://www.bikersrights.com/statistiks/ trauma.html.

11. Macnab AJ, Smith T, Gagnon FA, Macnab M. Effect of helmet wear on the incidence of head/face and cervical spine injuries in young skiers and snowboarders. Inj Prev. 2002;8:324-7.

12. Goslar PW, Crawford NR, Petersen SR, Wilson JR, Harrington T. Helmet use and associated spinal fractures in motorcycle crash victims. J Trauma. 2008;64:190-6.

13. Zhou SW, Zhang SQ, Yang Y, Song GQ. Study on cervical spine injuries in vehicle frontal impact. J Biomimetics, Biomaterials, and Tissue Engineering. 2011;9:69-80.

14. McIntosh AS, McCrory P. Preventing head and neck injury. Br J Sports Med. 2005;39:314-8.

15. Hagel BE, Russell K, Goulet C, NettelAguirre A, Pless IB. Helmet use and risk of neck injury in skiers and snowboarders. Am J Epidemiol. 2010;17:1134-43.

16. Mulligan RP, Mahabir RC. The prevalence of cervical spine injury, head injury or both with isolated and multiple craniomaxillofacial fractures. Plast Reconstr Surg. 2010;126:1647-51. 